\title{
Chiral Bistacrine Analogues: Synthesis, Cholinesterase Inhibitory Activity and a Molecular Modeling Approach
}

\author{
João P. B. Lopes, ${ }^{a}$ Jessie S. da Costa,${ }^{a}$ Marco A. Ceschi, *a Carlos A. S. Gonçalves, ${ }^{b}$ \\ Eduardo L. Konrath, ${ }^{c}$ Ana L. M. Karl, ${ }^{d}$ Isabella A. Guedes ${ }^{d}$ and Laurent E. Dardenne ${ }^{*, d}$ \\ anstituto de Química, Universidade Federal do Rio Grande do Sul, \\ Av. Bento Gonçalves, 9500, Campus do Vale, 91501-970 Porto Alegre-RS, Brazil
}

${ }^{b}$ Departamento de Bioquímica, Universidade Federal do Rio Grande do Sul, Rua Ramiro Barcelos, 2600, Prédio Anexo, 90035-003 Porto Alegre-RS, Brazil

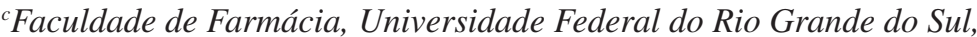
Av. Ipiranga, 2752, Santana, 90610-000 Porto Alegre-RS, Brazil

${ }^{d}$ Laboratório Nacional de Computação Científica, Av. Getulio Vargas, 333, 25651-075 Petrópolis-RJ, Brazil

\begin{abstract}
Cholinesterase enzymes are important targets for the therapy of Alzheimer's disease. Tacrine-based dual binding site cholinesterases inhibitors are potential disease-modifying anti-Alzheimer drug candidates. In the present work, we described the synthesis of a series of chiral homo- and heterodimers of bis(7)-tacrine connected by a heptylene chain as a spacer with the methyl substituent at the $\mathrm{C}-3$ position of the alicyclic region of tacrine nucleus and/or a chlorine atom attached to the C-6. Friedländer cyclocondensation between $(R)$ or $(S) 3$-methylcyclohexanone prepared from monoterpene pulegone and $o$-aminobenzoic acids in the presence of $\mathrm{POCl}_{3}$ afford 9-chloroacridines as intermediates, which were used to the synthesis of homo- and heterodimers. All compounds demonstrated to be potent inhibitors of acetylcholinesterase (AChE) at low nanomolar concentration and showed selectivity for $\mathrm{AChE}$ over butyrylcholinesterase (BuChE). Furthermore, the affinity difference between enantiomeric bis(7)-tacrine analogues series indicated some degree of stereoselectivity in the active site of AChE for chiral bis-cognitin compounds.
\end{abstract}

Keywords: bistacrine, chiral, cholinesterases, synthesis, molecular docking

\section{Introduction}

Alzheimer's disease (AD) is one of the leading causes of death among elderly people in the World, and its treatment remains a challenge for the pharmaceutical community. Nearly a million new cases per year it is expected to emerge by $2050 .^{1,2}$ The proposed cholinergic hypothesis of cognitive impairment has been accepted for decades to explain $\mathrm{AD}$ and is characterized by the loss of cholinergic basal forebrain, and their projections to the cerebral cortices. ${ }^{2,3}$ According to this hypothesis, the memory and cognitive decline well-marked in AD result from a deficit of the important neurotransmitter acetylcholine (ACh). In this context, the inhibition of cholinesterase enzymes (ChEs) that are responsible for the hydrolyses

*e-mail: mceschi@iq.ufrgs.br; dardenne @lncc.br of ACh emerge as a symptomatic treatment to relieve these symptoms. ${ }^{4-6}$ The current therapeutic options for $\mathrm{AD}$ are limited to three inhibitors of acetylcholinesterase $(\mathrm{AChEI}):^{4-8}$ donepezil (Aricept ${ }^{\circledR}$ ), rivastigmine $\left(\right.$ Exelon $^{\circledR}$ ) and galantamine $\left(\right.$ Razadyne $^{\circledR}$, Reminyl $\left.^{\circledR}\right)$. In addition, the $N$-methyl- $D$-aspartate (NMDA) receptor antagonist memantine $\left(\mathrm{Namenda}^{\circledR}\right)$ is also used. ${ }^{9-11}$ However, none of these therapeutic options represent a real cure.

The cholinesterase enzymes acetylcholinesterase (AChE) and butyrylcholinesterase (BuChE) are enzymes which are found in the central nervous system (CNS) and catalyze the hydrolysis of ACh efficiently but at different rates. ${ }^{9-12}$ However, as $\mathrm{AD}$ progresses, the activity of $\mathrm{AChE}$ decreases, while that of $\mathrm{BuChE}$ significantly increases and may even surpass the AChE activity. ${ }^{13,14}$

The acetylcholine binding site of AChE is located at the base of a deep hydrophobic channel measuring 
approximately $20 \AA$ in length. It is formed by a catalytic anionic site (CAS) composed by the catalytic triad Ser200, His440 and Glu327 and the anionic subsite which is defined by Trp84, Tyr130, Tyr330, and Phe331 amino acid residues..$^{15}$ At the entrance of the gorge, there is a specific peripheral anionic site (PAS) that exhibits an important conformational flexibility. It is composed of a set of aromatic residues Tyr70, Tyr121, Trp279, Tyr334 and the negatively charged Asp72. ${ }^{16}$ Furthermore, a line of recent evidences suggests that BuChE plays a key role in the etiology and progression of neurodegenerative diseases such as AD. ${ }^{17-20}$ It is suggested that $\mathrm{BuChE}$ is a key player in brain areas that influence the aggregation of neuritic $A \beta$ plaques due to the correlation between BuChE polymorphisms and the progression of cognitive impairment in dementia with Lewy bodies (DLB) and AD. ${ }^{21-23}$ It is also believed that $\mathrm{BuChE}$ is particularly important in individuals with more severe dementia, since its activity is increased with disease development. Therefore, compounds that can interact specifically with PAS or CAS residues are important in ChE inhibition and may help in prevention of $A \beta$ aggregation facilitated by AChE. ${ }^{24-26}$

Tacrine (1, THA) or 9-amino-1,2,3,4-tetrahydroacridine (Figure 1), sold under the name of Cognex, was the first approved drug introduced in AD therapy. THA is a reversible inhibitor and known as a classical cholinesterase inhibitor (ChEI) pharmacophore. ${ }^{27-30}$ However, its extensive use was limited since it showed various side effects and toxicity. Tacrine showed other pharmacological activities such as the blockage of potassium channels and inhibition of the neuronal uptake of noradrenaline, dopamine, and serotonin. ${ }^{31,32}$ Therefore, many efforts have been made for the synthesis of new tacrine analogues, with only a few dealing with the synthesis of chiral THA derivatives, although they showed important pharmacological activities. ${ }^{30,33-35}$ In Figure 1, we showed the regions of the structure of THA that can be modified by bioisosterism strategy. ${ }^{3}$ The quinoline nucleus present in (a) is the pharmacophore group in THA. This aromatic region usually interact with AChE binding site through cation-, ion-dipole- and hydrogen bonding interactions. The pyridin-4-amine nucleus, interrelated by the resonance of two aromatic rings, confers higher acidity to the primary amine (b). The amine becomes a hydrogen bond donor instead of a hydrogen bond acceptor since its non-bonding electron pair is involved in the resonance of the aromatic system. According to experimental and theoretical studies, the pyridine nitrogen (region (c)) is protonated under physiological conditions $\left(\mathrm{pKa}=9.8^{36}\right.$ experimentally measured and $\mathrm{pKa}=9.83 \pm 1.47$ according to the Epik ${ }^{37}$ prediction), conferring to tacrine some basicity. The alicyclic region (d) has low polarity and is able to establish hydrophobic interactions with the targeted enzymes. ${ }^{3}$ Computational studies performed about twenty years ago by Pang et al. ${ }^{14}$ tested the strategy of a double interaction of an inhibitor with the enzyme. ${ }^{38}$ The authors found that methylene chain spacers joining two units of tacrine moiety allowed a double interaction of the compound with the enzyme by binding simultaneously to the CAS and PAS..$^{14,38-40}$ These results lead the authors to perform the synthesis of alkylene-linked bis-tacrine compounds (Figure 1). ${ }^{40}$ Among the compounds obtained, the heptylene-linked bis-tacrine (2), also called bis(7)-cognitin or bis(7)-tacrine was found to be almost fifteen hundred times more potent against $\mathrm{AChE}$ than tacrine. These findings were ratified with crystallographic studies. ${ }^{41}$ In the binding mode observed for the dimer, a THA component is located at the CAS region, close to the enzyme catalytic triad, while the other THA component binds to PAS at the entrance of the catalytic gorge. ${ }^{42}$ After Pang et al..$^{14}$ first report, several examples of homo- or hetero-dimeric cholinesterase inhibitors (ChEIs), containing units of tacrine linked by an oligomethylene chain, have appeared in the literature. ${ }^{43}$
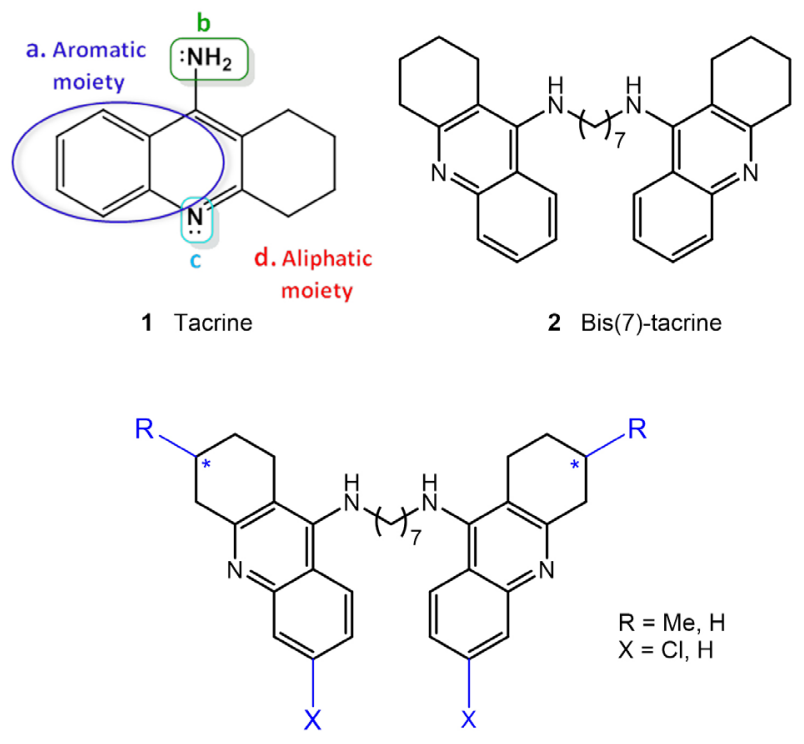

3 Chiral bis(7)-tacrine homo- and heterodimers

Figure 1. Structures of tacrine, bis(7)-tacrine and chiral dimers.

In June 2016, Schmidt et al. ${ }^{44}$ synthesized mono- and dimeric tacrine derivatives with different substitution patterns of tacrine moiety and linker lengths combining a set of substituents at aromatic region (a) and the alicyclic region (d). Dimers, especially, were found to have an antiplasmodial activity in the nanomolar concentration range and so regarded as new potent antimalarials.

We have previously described the synthesis of a series of chiral terpenic tacrine analogues as AChEIs using chiral 
ketones synthesized from natural monoterpenes in an optically active form. ${ }^{30}$ Within the studied series, (3R)-9-amino3-methyl-1,2,3,4-tetrahydroacridine was obtained in a completely regioselective manner from a cyclodehydration reaction with $(R)-(+)-3$-methylcyclohexanone and anthranilonitrile in the presence of $\mathrm{BF}_{3} . \mathrm{Et}_{2} \mathrm{O}$ as catalyst. ${ }^{45}$

Despite the plethora of synthetic and natural ChEIs, different extents of chiral selectivity have been observed for reversible, irreversible or pseudo-irreversible inhibitors. ${ }^{10,46-48}$ For instance, several studies of structural elements of ChEs are being gradually unraveled by X-ray crystallography, kinetic experiments and computational techniques. ${ }^{10}$ However, the lack of chiral prototypes as ChEIs in both enantiomeric forms is limited and demand further studies.

As part of our search of novel ChEIs based on tacrine units. ${ }^{30,49-51}$ we describe in the present study the synthesis of a series of chiral homo- and heterodimers of bis(7)-tacrine (3, Figure 1) with the methyl substituent at C-3 position (alicyclic region (d)) and/or chlorine atom in the $\mathrm{C}-6$ position (aromatic region (a)) connected by a heptylene chain as spacer. The compounds were tested as inhibitors of AChE and $\mathrm{BuChE}$, which were evaluated by molecular docking.

\section{Results and Discussion}

The chiral 3-methylcyclohexanones were obtained from natural monoterpene pulegone, commercially available in $(R)-(+)$ - and $(S)-(-)$ enantiomers. Due to cost consideration, we first adapted all reaction protocol in a small scale using the readily and abundantly available $(R)-(+)$-pulegone. Pulegone retro-aldol reaction afforded $(R)-(+)$ - and $(S)-(-)$ enantiomers in $70 \%$ yield and the observed optical activities were $+13^{\circ}$ and $-15^{\circ}$, respectively.

In order to synthesize the bis(7)-tacrine homodimers (3a-3b) and heterodimers (3c-3d) we performed the
Friedländer cyclocondensation with 3-methylcyclohexanone (4) and $o$-aminobenzoic acids $\mathbf{5}$ in the presence of $\mathrm{POCl}_{3}$ to afford 9-chloroacridines (6a-6c) regioselectively in good yields $60-80 \%$ (Scheme 1).

Next, the nucleophilic aromatic substitution reaction between 9-chloroacridines (6a-6c) and 1,7-diaminoheptane afforded the chiral homodimers (3a-3b) 63-81\% as shown in Scheme 2. The synthesis of chiral heterodimers required the preparation of precursor 9-(1,7-diaminoheptyl)1,2,3,4-tetraydroacridine (7) containing tacrine nucleus and the amino group separated by spacer chain, for subsequent $\mathrm{S}_{\mathrm{N}} \mathrm{Ar}$ reaction with the 9-chloroacridine $\mathbf{6 a}$. The reaction was performed according to a previously reported protocol affording (3c-3d) in good yields $44-80 \%$ as depicted in Table 1.

The inhibitory activities against $\mathrm{AChE}$ and BuChE of new chiral bis(7)-tacrine dimers are reported in Table 1, and are expressed as $\mathrm{IC}_{50}$ values. Bis(7)-tacrine was synthesized according to literature protocol and taken as a control compound in the set of experiments. ${ }^{40,50}$

The inhibitory activities against AChE and BuChE of new chiral bis(7)-tacrine dimers, together with that of bis(7)-tacrine taken as a reference compound in the set of experiments, are reported in Table 1, and are expressed as $\mathrm{IC}_{50}$ values.

Both enantiomeric bis(7)-tacrine analogues series were found to be potent inhibitors of cholinesterases with $\mathrm{IC}_{50}$ in the nanomolar concentration scale. The homodimer $(R, R)-\mathbf{3 b}(\mathrm{X}=\mathrm{Cl})$ was the most active AChE inhibitor in the homodimers series and the most active of all compounds was the heterodimer $(R)-3 d(X=C l)$ with $\mathrm{IC}_{50}$ of $4.73 \mathrm{nM}$ (entry 3) and $2.80 \mathrm{nM}$ (entry 7), respectively, both of them more active than bis(7)-tacrine (entry 9). The selectivity for AChE was observed for all compounds, and some dimers $(R, R)-\mathbf{3 b}$ and $(R)-\mathbf{3 c}$ did not inhibit BuChE enzyme. When comparing the homodimers and heterodimers containing<smiles>[R]C1CCCC(=O)C1</smiles>
$(R)$ and $(S)-4$<smiles>[X]c1ccc(C(=O)O)c(N)c1</smiles>

5

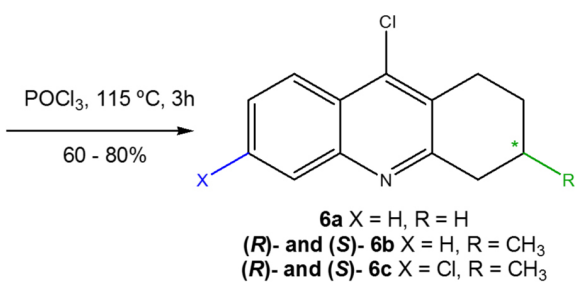<smiles>NNc1c2c(nc3ccccc13)CCCC2</smiles>

7

Scheme 1. Synthesis of 9-chloro- and 9-(1,7-diaminoheptyl)-acridine derivatives, 6 and 7. 


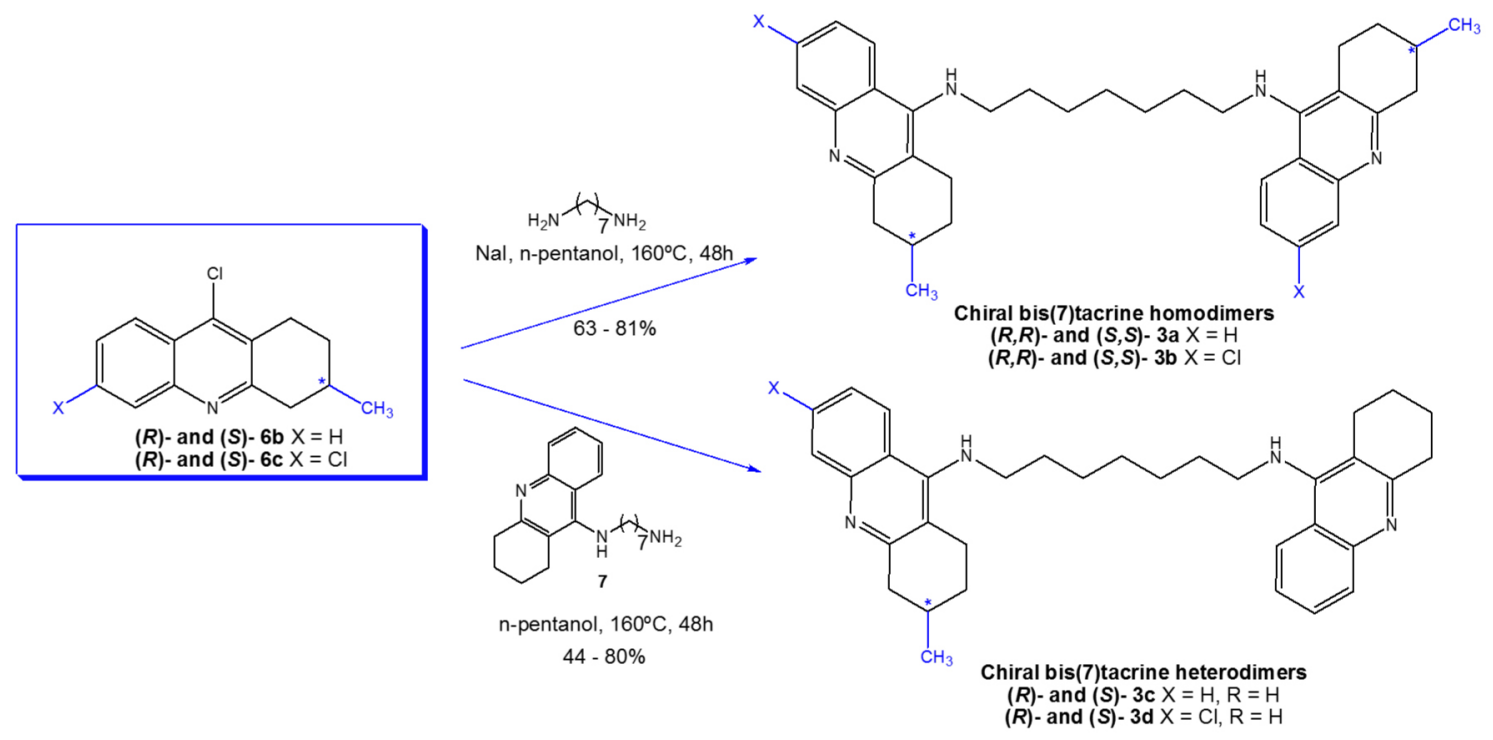

Scheme 2. Synthesis of chiral bis(7)-tacrine homodimers (3a-3b) and heterodimers (3c-3d).

Table 1. Inhibitory activity on $\mathrm{AChE}$ and $\mathrm{BuChE}$, and $\mathrm{IC}_{50}$ ratio of chiral bis(7)-tacrine dimers

\begin{tabular}{|c|c|c|c|c|c|c|c|}
\hline \multirow{2}{*}{ entry } & \multirow{2}{*}{ Compound } & \multirow{2}{*}{$\mathrm{X}$} & \multirow{2}{*}{ Yield $^{\mathrm{a}}$ \% } & \multirow{2}{*}[\alpha]{$_{\mathrm{D}}^{20 \mathrm{~b}}$} & \multicolumn{2}{|c|}{$\mathrm{IC}_{50}{ }^{\mathrm{c}} / \mathrm{nM}$} & \multirow{2}{*}{$\mathrm{IC}_{50}$ ratio $\mathrm{BuChE} / \mathrm{AChE}$} \\
\hline & & & & & AChE & $\mathrm{BuChE}$ & \\
\hline 1 & $(R, R)-\mathbf{3 a}$ & $\mathrm{H}$ & 73 & $+18^{\circ}(\mathrm{c} 1.50)$ & $11.21 \pm 3.41$ & $80.03 \pm 8.46$ & 7.14 \\
\hline 2 & $(S, S)-\mathbf{3 a}$ & $\mathrm{H}$ & 63 & $-17^{\circ}(\mathrm{c} 1.54)$ & $7.64 \pm 0.45$ & $128.06 \pm 5.31$ & 16.76 \\
\hline 3 & $(R, R)-\mathbf{3 b}$ & $\mathrm{Cl}$ & 81 & $+14^{\circ}(\mathrm{c} 0.57)$ & $4.73 \pm 0.67$ & n.a. & - \\
\hline 4 & $(S, S)-\mathbf{3 b}$ & $\mathrm{Cl}$ & 69 & $-12^{\circ}(\mathrm{c} 0.59)$ & $16.08 \pm 1.85$ & $114.59 \pm 2.85$ & 7.13 \\
\hline 5 & $(R)-3 \mathbf{c}$ & $\mathrm{H}$ & 80 & $+5^{\circ}(\mathrm{c} 0.74)$ & $76.23 \pm 15.16$ & n.a. & - \\
\hline 6 & $(S)-\mathbf{3 c}$ & $\mathrm{H}$ & 68 & $-4^{\circ}(\mathrm{c} 0.73)$ & $13.73 \pm 1.12$ & $38.03 \pm 3.49$ & 2.77 \\
\hline 7 & $(R)-\mathbf{3 d}$ & $\mathrm{Cl}$ & 44 & $+10^{\circ}(\mathrm{c} 1.12)$ & $2.80 \pm 0.92$ & $44.82 \pm 3.06$ & 16.0 \\
\hline 8 & $(S)-\mathbf{3 d}$ & $\mathrm{Cl}$ & 46 & $-4^{\circ}(\mathrm{c} 0.85)$ & $9.97 \pm 1.01$ & $92.43 \pm 7.07$ & 9.27 \\
\hline 9 & bis(7)-tacrine & - & - & - & $5.33 \pm 0.48$ & $38.30 \pm 10.93$ & 7.18 \\
\hline
\end{tabular}

${ }^{\mathrm{a}} \mathrm{All}$ yields refer to purified product; ${ }^{\mathrm{b}}$ optical rotations were obtained in $\mathrm{CH}_{2} \mathrm{Cl}_{2} ;{ }^{\mathrm{c}} \pm 95 \%$ confidence limits. n.a.: not active.

the $\mathrm{H}$ and $\mathrm{Cl}$ substituent it is observed that the presence of chlorine atom increased the inhibition of AChE activity, except for the $(S, S)$-3b homodimer. On the other hand, this substitution affected the inhibition of $\mathrm{BuChE}$ in different ways, decreasing the activity of $(R)$-series of homodimers and $(S)$-series heterodimers, but increasing the activity of $(R)$-series of heterodimers, and did not affect significantly the $(S)$-series of homodimers. Regarding the stereoselectivity, it was observed that the AChE showed a preference for $(R)$-series of homo and heterodimers with chlorine atom in the tacrine moiety (entries 3 and 7) and for the $(S)$-series of dimers without this chlorine atom (entries 2 and 6). The affinity difference between the stereoisomers indicates some degree of stereoselectivity in the active site of $\mathrm{AChE}$ for chiral bis-cognitin compounds. However, in the same series, BuChE showed a strong stereoselectivity for $(S, S)-\mathbf{3 b}$ (with chlorine) and $(S)-\mathbf{3 c}$.
According to the binding affinity predictions (i.e., GlideScore, DockTScore), all compounds were predicted to be highly potent inhibitors of AChE in the range of low nanomolar concentration (Table 2) obtaining only small differences between the predicted affinities. The most potent inhibitor (i.e., $(R)$-3d) obtained the best score according to the DockTScore predictions. The lowest energy binding mode of all inhibitors were predicted with the 2CKM conformation of AChE (residue numbers of Tetronace californica AChE are cited in plain text with the corresponding numbers of Torpedo californica AChE in parenthesis and in italics), with an overall binding mode similar to the co-crystallized inhibitor bis(7)-tacrine (Figure 2). The main characteristic of this binding mode is the parallel packing of a tacrine moiety with $\operatorname{Trp} 276$ (279) and Tyr67 (70) from PAS and the conserved interactions with CAS. 
Table 2. Results of docking and binding affinity prediction according to the GlideScore and DockTScore, and $\mathrm{IC}_{50}$ ratio of chiral bis(7)-tacrine dimers

\begin{tabular}{lcccc}
\hline Compound & $\mathrm{X}$ & $\mathrm{AChE}^{\mathrm{a}} / \mathrm{nM}$ & GlideScore $^{\mathrm{b}}$ & DockTScore $^{\mathrm{b}}$ \\
\hline$(R, R)-3 \mathbf{a}$ & $\mathrm{H}$ & $11.21 \pm 3.41$ & -14.554 & -14.030 \\
$(S, S)$-3a & $\mathrm{H}$ & $7.64 \pm 0.45$ & -14.994 & -14.076 \\
$(R, R)-3 \mathbf{b}$ & $\mathrm{Cl}$ & $4.73 \pm 0.67$ & -14.549 & -14.207 \\
$(S, S)$-3b & $\mathrm{Cl}$ & $16.08 \pm 1.85$ & -14.467 & -14.123 \\
$(R)-3 \mathbf{c}-\mathbf{7}$ & $\mathrm{H}$ & $76.23 \pm 15.16$ & -14.291 & -13.867 \\
$(S)-3 \mathbf{c}-6$ & $\mathrm{H}$ & $13.73 \pm 1.12$ & -14.521 & -13.834 \\
$(R)-3 \mathbf{3 d}$ & $\mathrm{Cl}$ & $2.80 \pm 0.92$ & -14.526 & -14.223 \\
$(S)-3 d$ & $\mathrm{Cl}$ & $9.97 \pm 1.01$ & -14.817 & -14.076 \\
Bis(7)-tacrine & - & $5.33 \pm 0.48$ & -15.333 & -13.907 \\
\hline
\end{tabular}

${ }^{\mathrm{a}} \pm 95 \%$ confidence limits; ${ }^{\mathrm{b}}$ predicted binding affinities given in $\mathrm{kcal} \mathrm{mol}^{-1}$.

The overall binding modes of the compounds are very similar, interacting with both CAS and PAS (Figures 2-4). In the case of homodimers (Figure 3), one tacrine moiety is packed between Trp276 (279) and Tyr67 (70) from PAS through pi-stacking interactions (Figure 3A). For the compounds where the chlorine atom is present, the halogen is oriented toward Glu275 (278), probably interacting through a halogen bond. At the opposite side of tacrine, the methyl group is totally exposed to the solvent, which might decrease the binding affinity. The other tacrine moiety interacts in the bottom of the gorge (Figure 3B) performing the conserved interactions observed for tacrine: $(i)$ hydrogen bond between charged nitrogen from pyridine with the

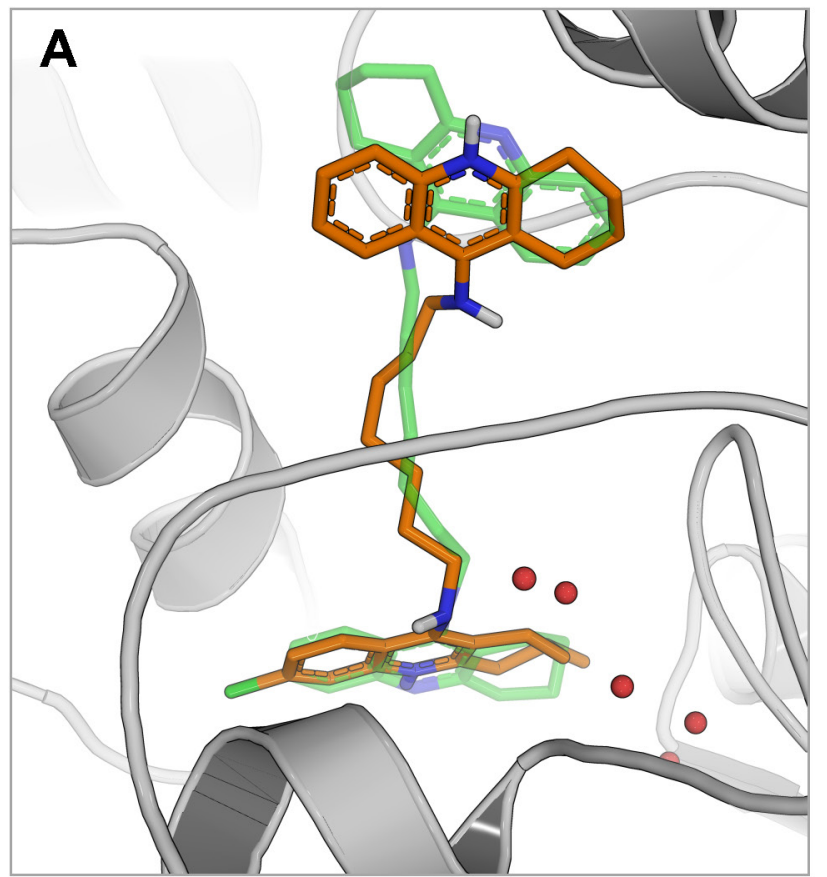

His437 (440) main chain, (ii) quinoline system sandwiched between Trp81 (84) and Phe327 (330) interacting through pi-stacking interactions, (iii) terpene ring oriented to CAS. The chlorine atom in the 6-position is predicted to interact with the allosteric hydrophobic site formed by Trp429 (432), Met433 (436) and Ile436 (439), while the methyl group is oriented to CAS. The main difference between $R$ and $S$ configurations is that the former provides the methyl group near Glu196 (199) and the conserved water $\mathrm{HOH} 2062$, while the last allows the methyl group to be located near Ser197 (200) on a larger cavity more exposed to the solvent. Despite the differences of the binding modes, it is not clear the influence of such interactions for the binding affinities observed for $R$ and $S$ compounds.

In the case of heterodimers (Figure 4), the tacrine moiety with substituents exhibited a preference for the bottom of the gorge, performing the same interactions observed for tacrine with CAS and previously described.

According to the docking results, it is possible to conclude that: $(i)$ the presence of a chlorine atom increases binding affinity due to the hydrophobic interactions with CAS and a possible halogen bond with Glu275 (278) in PAS, (ii) for homodimers with the presence of chlorine, the methyl group in PAS is predicted to be exposed to the solvent and probably contributes negatively for the binding affinity. Despite the small differences, the predicted affinities provided by DockTScore (Table 2) follow qualitatively the experimental results when comparing $R \times S$ and $\mathrm{Cl} \times \mathrm{H}$ compounds. Furthermore, it is probable

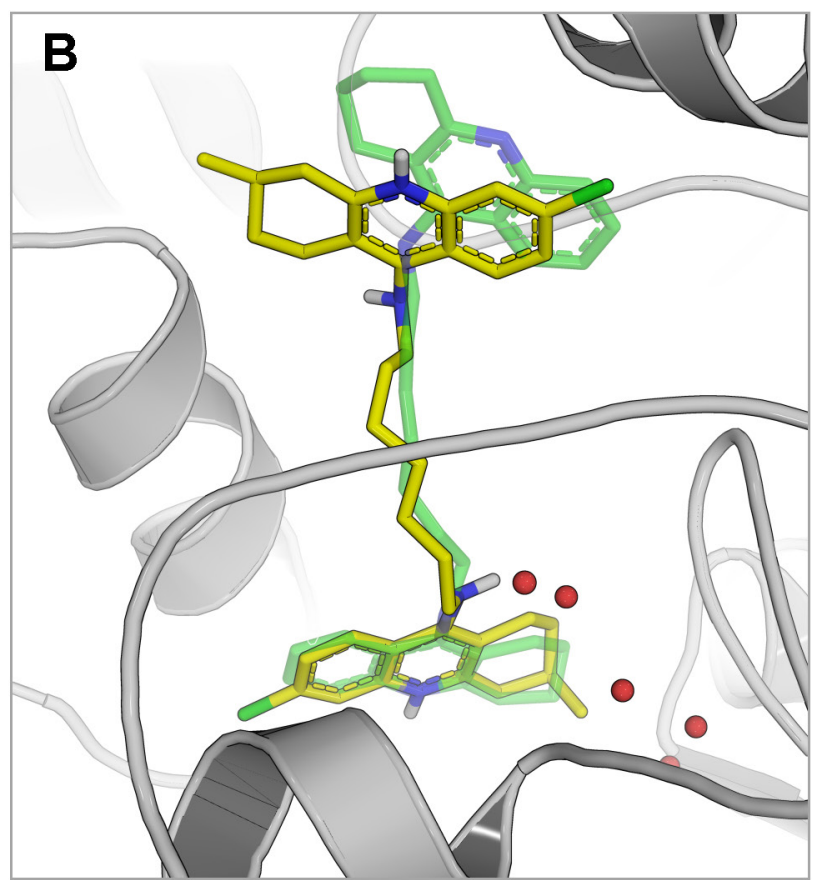

Figure 2. Overall binding modes predicted for (A) the heterodimer $(R)-\mathbf{3 d}$ and (B) the homodimer $(R, R)-\mathbf{3 b}$, superposed with the experimental conformation of bis(7)-tacrine (colored green) observed in the 2CKM complex. Structural waters are represented as red spheres. 


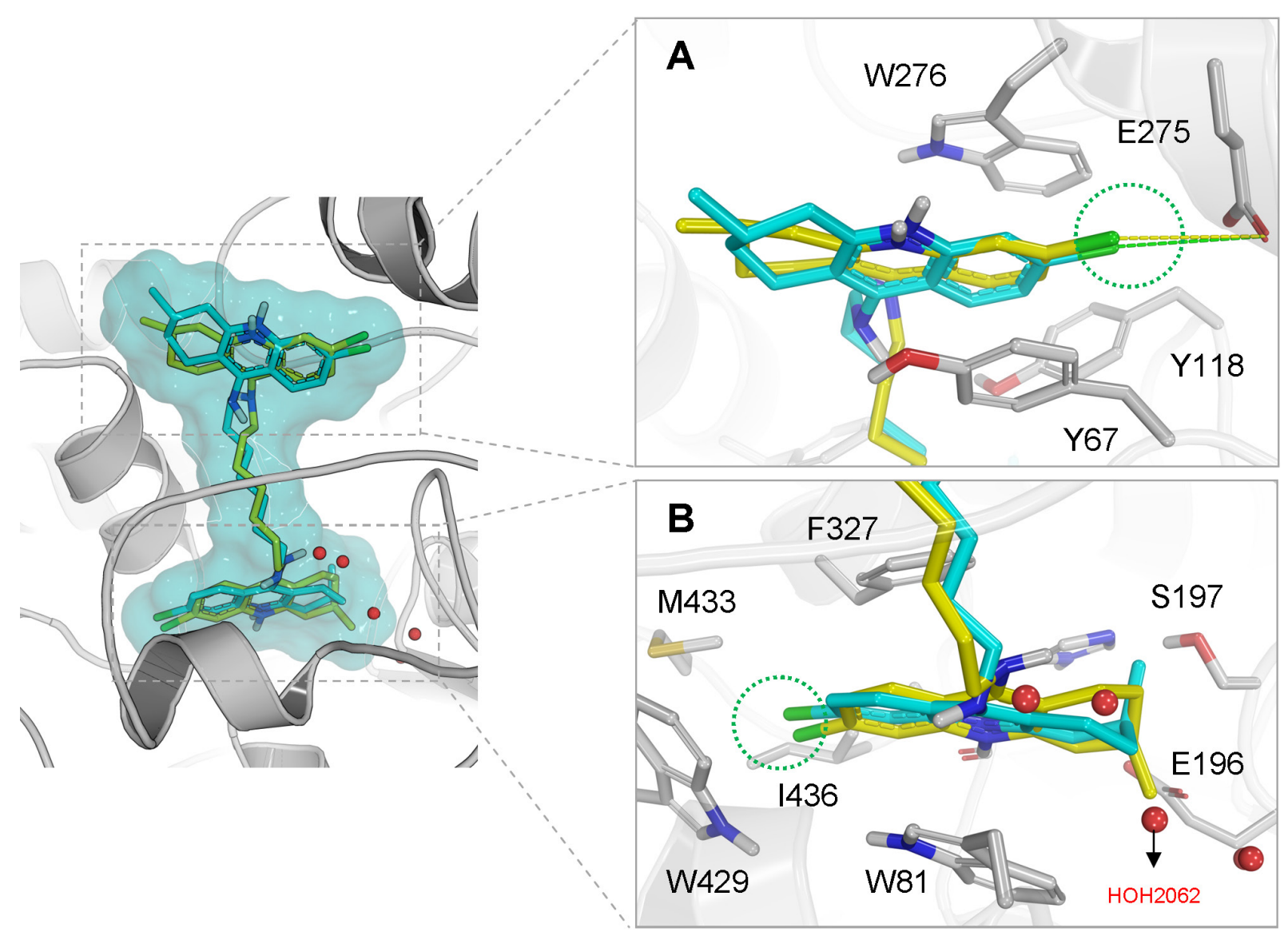

Figure 3. Predicted binding modes of the homodimers $(R, R)-\mathbf{3 b}$ (yellow) and $(S, S)-\mathbf{3 b}$ (blue) with the 2CKM conformation of AChE (Tetronace californica $\mathrm{AChE}$ numbering). The chlorine atoms are highlighted with dashed green line. Structural waters are represented as red spheres.

that there is a cooperativity effect between the chlorine atom and the methyl group that we were incapable to explore through docking experiments, requiring more sophisticated studies such as molecular dynamics and quantum calculations for further analyses.

\section{Conclusions}

In summary, we have synthesized a new series of chiral bis(7)-tacrines and tested its ability to inhibit cholinesterase enzymes. Both enantiomeric bis(7)-tacrine analogues series were found to be potent inhibitors of $\mathrm{AChE}$ and $\mathrm{BuChE}$ with $\mathrm{IC}_{50}$ in the nanomolar concentration scale, according to the AChE binding affinity predictions (i.e., GlideScore, DockTScore), possessing only small differences between the predicted affinities for all tested compounds. Regarding the stereoselectivity, it was observed that the AChE showed a preference for $(R)$-series of homo and heterodimers with chlorine atom in the tacrine moiety and for the $(S)$-series of dimers without this chlorine atom. The affinity difference between the stereoisomers indicates some degree of stereoselectivity in the active site of AChE for chiral bis-cognitin compounds. In a docking approach, the overall binding modes of the compounds are very similar, interacting with both CAS and PAS of AChE. Despite the differences of the binding modes observed for the $R$ and $S$ configurations, it is not clear the influence of the resulting interactions for the binding affinities observed for $R$ and $S$ compounds.

\section{Experimental}

\section{Chemistry}

All melting points were determined in open glass capillaries using a Büchi M-565 apparatus. Infrared (IR) spectra were recorded on a Varian 640-IR spectrometer in $\mathrm{KBr}$ disks. ${ }^{1} \mathrm{H}$ and ${ }^{13} \mathrm{C}$ nuclear magnetic resonance (NMR) spectra were recorded in $\mathrm{CDCl}_{3}$ solution on a Varian VNMRS $300 \mathrm{MHz}$ spectrometer. The assignment of chemical shifts is based on standard NMR experiments $\left({ }^{1} \mathrm{H}\right.$; ${ }^{13} \mathrm{C}$-APT (attached proton test); ${ }^{1} \mathrm{H},{ }^{1} \mathrm{H}-\mathrm{COSY}$ (correlation spectroscopy); ${ }^{1} \mathrm{H},{ }^{13} \mathrm{C}-\mathrm{HMQC}$ (heteronuclear multiple quantum correlation)). Chemical shifts $(\delta)$ are given in part per million from the peak of tetramethylsilane $(\delta 0.00 \mathrm{ppm})$ as internal standard in ${ }^{1} \mathrm{H}$ NMR or from the solvent peak 


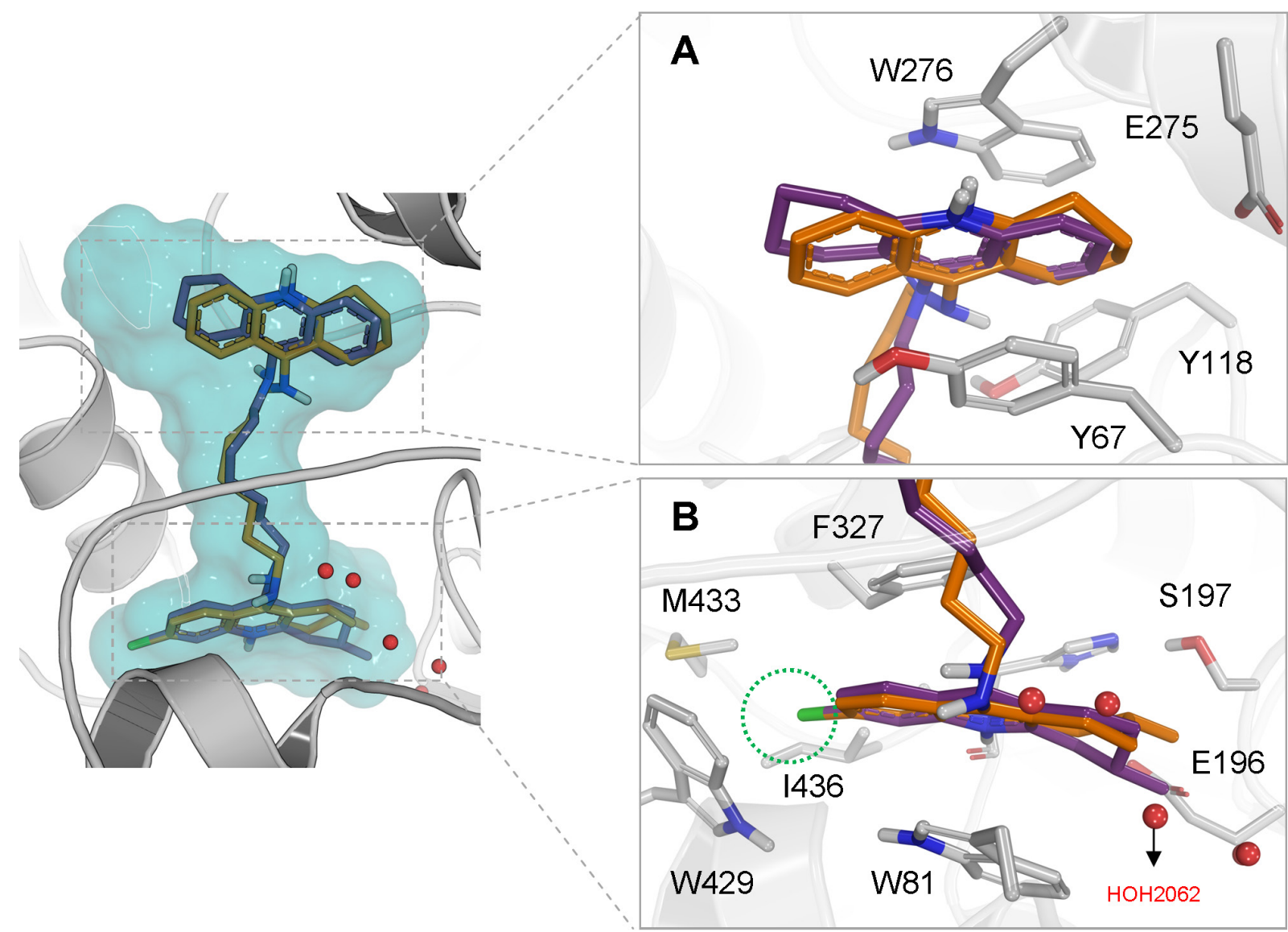

Figure 4. Predicted binding modes of the heterodimers $(R)-3 \mathbf{d}$ (orange) and $(S)$-3d (purple) with the 2CKM conformation of AChE (Tetronace californica $\mathrm{AChE}$ numbering). The chlorine atom is highlighted with dashed green line. Structural waters are represented as red spheres.

of $\mathrm{CDCl}_{3}(\delta 77.00 \mathrm{ppm})$ in ${ }^{13} \mathrm{C}$ NMR; and multiplicities are given as s (singlet), $\mathrm{d}$ (doublet), dd (double doublet), $\mathrm{t}$ (triplet), q (quartet), $\mathrm{m}$ (multiplet) or br (broad); coupling constants $(J)$ are given in Hz. High resolution mass spectrometry with eletrospray ionization (HRMS-ESI) data on the positive mode was collected on a Micromass Q-Tof instrument from Waters (Manchester, UK). Samples were infused from a $100 \mathrm{~mL}$ Hamilton syringe at flow rate range from 5 to $10 \mathrm{~mL} \mathrm{~min}^{-1}$, depending on the sample. The instrument settings were the following: capillary voltage $3000 \mathrm{~V}$, cone voltage $33 \mathrm{~V}$, extraction cone voltage $2.5 \mathrm{~V}$, desolvation gas temperature $100^{\circ} \mathrm{C}$. Nitrogen was used as the desolvation gas. Methanol (Tedia, HPLC grade) was used as solvent for the analyzed samples and filtered prior to injection. Optical rotations were measured in a PerkinElmer 341 polarimeter with a $0.1 \mathrm{dm}$ cell at a temperature of $20{ }^{\circ} \mathrm{C}$, sample were dissolved in dichloromethane and the concentrations are expressed in $\mathrm{g}$ per $100 \mathrm{~mL}$ of solvent. Purification by column chromatography was carried out on silica gel 60 (70-230 mesh). Analytical thin layer chromatography (TLC) was conducted on aluminium plates with $0.2 \mathrm{~mm}$ of silica gel 60F-254 (MachereyNagel). $(R)$ - and $(S)$-3-methylciclohexanone $(4),{ }^{45}$ chloroacridines $(\mathbf{6 a - 6 c})^{34,44}$ and compound $\mathbf{7}^{52}$ were synthesized according to the previous literature procedure.

Specific rotation, melting point, ${ }^{1} \mathrm{H}$ and ${ }^{13} \mathrm{C}$ NMR data for compounds $(R)-6 \mathbf{b}$ and $(S)-6 \mathbf{b}^{34}$

$(R)-6 \mathbf{b}[\alpha]_{\mathrm{D}}{ }^{20}+64^{\circ}\left(\mathrm{c} 0.44 ; 20^{\circ} \mathrm{C}, \mathrm{CHCl}_{3}\right)$, m.p. $58^{\circ} \mathrm{C}$; $(S)-6 \mathbf{b}[\alpha]_{\mathrm{D}}{ }^{20}-62^{\circ}\left(\mathrm{c} 0.45 ; 20{ }^{\circ} \mathrm{C}, \mathrm{CHCl}_{3}\right)$, m.p. $58^{\circ} \mathrm{C}$; ${ }^{1} \mathrm{H}$ NMR $\left(300 \mathrm{MHz}, \mathrm{CDCl}_{3}\right) \delta 1.14(\mathrm{~d}, 3 \mathrm{H}, J 6.6 \mathrm{~Hz})$, $1.44-1.53(\mathrm{~m}, 1 \mathrm{H}), 1.95-2.06(\mathrm{~m}, 2 \mathrm{H}), 2.66-2.73(\mathrm{~m}, 1 \mathrm{H})$, 2.82-2.90 (m, 1H), 3.15-3.23 (m, 2H), 7.51 (ddd, $1 \mathrm{H}, J 8.4$, 6.8 and $1.2 \mathrm{~Hz}$ ), 7.64 (ddd, $1 \mathrm{H}, J$ 8.4, 6.8 and $1.5 \mathrm{~Hz}$ ), 7.96 $(\mathrm{d}, 1 \mathrm{H}, J 8.4 \mathrm{~Hz}), 8.16(\mathrm{~d}, 1 \mathrm{H}, J 8.4 \mathrm{~Hz}) ;{ }^{13} \mathrm{C} \mathrm{NMR}(75 \mathrm{MHz}$, $\left.\mathrm{CDCl}_{3}\right) \delta 21.5,27.1,28.9,30.6,42.5,123.6,125.4,128.3$, 128.7, 129.2, 141.3, 146.8, 159.3.

Specific rotation, melting point, ${ }^{1} \mathrm{H}$ and ${ }^{13} \mathrm{C}$ NMR data for compounds $(R)-6 \mathbf{c}$ and $(S)-6 \mathbf{c}^{44}$

$(R)-6 \mathbf{c}[\alpha]_{\mathrm{D}}^{20}+60^{\circ}\left(\mathrm{c} 1.03 ; 20{ }^{\circ} \mathrm{C}, \mathrm{CH}_{2} \mathrm{Cl}_{2}\right)$; m.p. $88^{\circ} \mathrm{C}$; $(S)-6 \mathbf{c}[\alpha]_{\mathrm{D}}{ }^{20}-59^{\circ}\left(\mathrm{c} 0.99 ; 20{ }^{\circ} \mathrm{C}, \mathrm{CH}_{2} \mathrm{Cl}_{2}\right)$; m.p. $88^{\circ} \mathrm{C}$; ${ }^{1} \mathrm{H}$ NMR $\left(300 \mathrm{MHz}, \mathrm{CDCl}_{3}\right) \delta 1.14(\mathrm{~d}, 3 \mathrm{H}, J 6.0 \mathrm{~Hz})$, 1.45-1.56 (m, 1H), 1.95-2.09 (m, 2H), 2.63-2.72 (m, 1H), 2.79-2.90 (m, 1H), 3.12-3.22 (m, 2H), 7.45 (dd, 1H, J 9.0 and $3.0 \mathrm{~Hz}), 7.96(\mathrm{~d}, 1 \mathrm{H}, J 3.0 \mathrm{~Hz}), 8.06(\mathrm{~d}, 1 \mathrm{H}, J 9.0 \mathrm{~Hz})$; 
${ }^{13} \mathrm{C}$ NMR (75 MHz, $\left.\mathrm{CDCl}_{3}\right) \delta 21.4,27.0,28.8,30.5,42.3$, $123.8,125.1,127.3,127.6,128.6,135.1,141.2,147.0,160.7$.

Procedure for the preparation of chiral homodimers: (3R)-N-(7-((R)-1,2,3,4-tetrahydro-3-methylacridin9-ylamino)heptyl)-1,2,3,4-tetrahydro-3-methylacridin9-amine $((R)-3 \mathbf{a})$ and $(3 S)-N-(7-((S)-1,2,3,4$-tetrahydro3-methylacridin-9-ylamino)heptyl)-1,2,3,4-tetrahydro3-methylacridin-9-amine ((S)-3a)

1,7-Diaminoheptane $(0.15 \mathrm{mmol}),(R)$ - or $(S)$-6b $(0.3 \mathrm{mmol})$ and sodium iodide $(0.02 \mathrm{mmol})$ were dissolved in $1.0 \mathrm{~mL}$ of $n$-pentanol and the mixture was maintained at $160{ }^{\circ} \mathrm{C}$ with stirring during 48 hours. After this time, the solvent was removed in vacuum and the mixture was diluted in $10 \mathrm{~mL}$ of $\mathrm{CH}_{2} \mathrm{Cl}_{2}$. The organic layer was washed with $\mathrm{NaOH} 10 \%$ and $\mathrm{NaCl}$ saturated aqueous solution and dried by anhydrous $\mathrm{Na}_{2} \mathrm{SO}_{4}$. Dichloromethane was removed under reduced pressure and the crude product was purified by column chromatography on silica gel.

After column chromatography (eluting with hexaneethyl acetate-triethylamine, 90:9:1, gradient until 50:49:1), $(R)-\mathbf{3 a}$ and $(S)$-3a were obtained as a yellow solid in $73 \%$ yield, m.p. 78-80 ${ }^{\circ} \mathrm{C}$; IR (KBr) $v_{\max } / \mathrm{cm}^{-1} 3410,2922$, 2856, 1615, 1581, 1561, 1499, 1418, 1357, 760; ${ }^{1} \mathrm{H}$ NMR $\left(300 \mathrm{MHz}, \mathrm{CDCl}_{3}\right) \delta 1.12(\mathrm{~d}, 6 \mathrm{H}, J 6.0 \mathrm{~Hz}), 1.32-1.42(\mathrm{~m}$, $6 \mathrm{H}), 1.43-1.55(\mathrm{~m}, 2 \mathrm{H}), 1.58-1.70(\mathrm{~m}, 4 \mathrm{H}), 1.92-2.09(\mathrm{~m}$, $4 \mathrm{H}), 2.58-2.72(\mathrm{~m}, 4 \mathrm{H}), 2.75-2.86(\mathrm{~m}, 2 \mathrm{H}), 3.09-3.20(\mathrm{~m}$, $2 \mathrm{H}), 3.40-3.55$ (m, 4H), 3.92 (s, 2H), 7.33 (ddd, $1 \mathrm{H}, J$ 8.4, 7.7 and $1.2 \mathrm{~Hz}$ ), 7.54 (ddd, $1 \mathrm{H}, J$ 8.4, 7.5 and $1.2 \mathrm{~Hz}$ ), 7.87-7.98 (m, 4H); ${ }^{13} \mathrm{C}$ NMR (75 MHz, $\left.\mathrm{CDCl}_{3}\right) \delta 21.5$, 24.3, 26.8, 28.8, 29.0, 30.9, 31.6, 42.4, 49.3, 115.2, 120.1, $122.8,123.5,128.1,128.7,147.6,150.5,158.3 ;(R)-3 \mathbf{a}$ $[\alpha]_{\mathrm{D}}^{20}+18^{\circ}(\mathrm{c} 1.50),(S)-\mathbf{3 a}[\alpha]_{\mathrm{D}}{ }^{20}-17^{\circ}(\mathrm{c} 1.54)$, HRMS-ESI calcd. for $[\mathrm{M}-\mathrm{H}]^{+}: 521.3639$, found: 521.3631 .

Procedure for the preparation of chiral homodimers: (6R)-N-(7-((R)-3-chloro-5,6,7,8-tetrahydro-6-methylacridin9-ylamino)heptyl)-3-chloro-5, 6, 7, 8-tetrahydro6 -methylacridin-9-amine $((R)-3 \mathbf{b})$, and $(6 S)-\mathrm{N}-(7-((S)$ 3-chloro-5,6,7,8-tetrahydro-6-methylacridin-9-ylamino) heptyl)-3-chloro-5,6,7,8-tetrahydro-6-methylacridin9-amine, ((S)-3b)

1,7-Diaminoheptane $(0.15 \mathrm{mmol}),(R)$ - or $(S)$-6c $(0.3 \mathrm{mmol})$ and sodium iodide $(0.02 \mathrm{mmol})$ were dissolved in $1.0 \mathrm{~mL}$ of $n$-pentanol and the mixture was maintained at $160{ }^{\circ} \mathrm{C}$ with stirring during 48 hours. After this time, the reaction was treated and purified as $\mathbf{3} \mathbf{a}$ procedure.

Yellow solid (81\% yield); m.p. $54-56{ }^{\circ} \mathrm{C}$; IR $(\mathrm{KBr})$ $v_{\max } / \mathrm{cm}^{-1} 3411,2924,2854,1607,1489,1419 ;{ }^{1} \mathrm{H}$ NMR $\left(300 \mathrm{MHz}, \mathrm{CDCl}_{3}\right) \delta 1.11(\mathrm{~d}, 6 \mathrm{H}, J 6.6 \mathrm{~Hz}), 1.33-1.52(\mathrm{~m}$, $10 \mathrm{H}), 1.58-1.70(\mathrm{~m}, 4 \mathrm{H}), 1.85-2.08(\mathrm{~m}, 4 \mathrm{H}), 2.50-2.82(\mathrm{~m}$, $6 \mathrm{H}), 3.03-3.17$ (m, 2H), 3.47 (t, 4H, J 7.2 Hz), 3.89-4.04 (sl, 2H), 7.21-7.30 (m, 2H), 7.81-7.97 (m, 4H); ${ }^{13} \mathrm{C}$ NMR (75 MHz, $\left.\mathrm{CDCl}_{3}\right) \delta 21.4,24.1,26.7,28.7,29.0,30.8,31.6$, 42.2, 49.4, 115.0, 118.2, 124.1, 124.6, 127.4, 133.9, 148.0, $150.6,159.2 ;(R)-3 \mathbf{b}[\alpha]_{\mathrm{D}}^{20}+14^{\circ}(\mathrm{c} 0.57),(S)-3 \mathbf{b}[\alpha]_{\mathrm{D}}^{20}-12^{\circ}$ (c $0.59 \mathrm{CH}_{2} \mathrm{Cl}_{2}$ ), HRMS-ESI calcd. for $[\mathrm{M}-\mathrm{H}]^{+}: 589.2859$, found: 589.2866 .

General procedure for the preparation of chiral heterodimers 3c-3d

Compound $7(0.20 \mathrm{mmol})$ and $\mathbf{6 b}$ or $\mathbf{6 c}(0.30 \mathrm{mmol})$ were dissolved in $1.0 \mathrm{~mL}$ of $n$-pentanol and the mixture was maintained at $160{ }^{\circ} \mathrm{C}$ with stirring during 48 hours under inert atmosphere. After this time, the solvent was removed in vacuum and the mixture was diluted in $10 \mathrm{~mL}$ of $\mathrm{CH}_{2} \mathrm{Cl}_{2}$. The organic layer was washed with $\mathrm{NaOH} 10 \%$ and $\mathrm{NaCl}$ saturated aqueous solution and dried by anhydrous $\mathrm{Na}_{2} \mathrm{SO}_{4}$. Dichloromethane was removed under reduced pressure and the crude product was purified by column chromatography (eluting with hexane-ethyl acetate-triethylamine, 90:9:1, gradient until 50:49:1) to give the desired product.

$N$-(7-((R)-1,2,3,4-Tetrahydro-3-methylacridin-9-ylamino) heptyl)-5,6,7,8-tetrahydroacridin-9-amine $((R)-3 \mathbf{c})$ and $N$-(7-((S)-1,2,3,4-tetrahydro-3-methylacridin-9-ylamino) heptyl)-5,6,7,8-tetrahydroacridin-9-amine ((S)-3c)

The heterodimers $(R)$ - and $(S)-\mathbf{3 c}$ were obtained according to general procedure to give a yellow solid (80\% yield); m.p. 50-52 ${ }^{\circ} \mathrm{C}$; IR (KBr) $v_{\max } / \mathrm{cm}^{-1} 3411,2391$, 2853, 1615, 1580, 1561, 1498, 760; ${ }^{1} \mathrm{H}$ NMR (300 MHz, $\left.\mathrm{CDCl}_{3}\right) \delta 1.11(\mathrm{~d}, 3 \mathrm{H}, J 6.3 \mathrm{~Hz}), 1.23-1.76(\mathrm{~m}, 10 \mathrm{H})$, 1.82-2.17 (m, 6H), 2.52-2.90 (m, 5H), 3.03-3.23 (m, 4H), 3.43-3.62 (s, 4H), 4.02-4.18 (sl, 2H), 7.30-7.42 (m, 2H), 7.48-7.63 (m, 2H), 7.88-8.17 (m, 4H); ${ }^{13} \mathrm{C}$ NMR (75 MHz, $\left.\mathrm{CDCl}_{3}\right) \delta 21.4,21.5,22.5,22.9,23.1,24.2,24.6,26.8,28.5$, 28.7, 29.0, 29.6, 30.4, 30.8, 31.6, 33.5, 41.8, 49.3, 114.8, $115.4,119.7,122.8,122.9,123.7,124.2,128.0,128.6$, 129.3, 146.7, 146.8, 151.0, 151.1, 157.6, 157.8; (R)-3c $[\alpha]_{\mathrm{D}}^{20}+5^{\circ}(\mathrm{c} 0.74),(S)-3 \mathbf{c}[\alpha]_{\mathrm{D}}^{20}-4^{\circ}(\mathrm{c} 0.73)$, HRMS-ESI calcd. for $[\mathrm{M}-\mathrm{H}]^{+}$: 507.3482, found: 507.3672.

$N$-(7-((R)-3-Chloro-5,6,7,8-tetrahydro-6-methylacridin9-ylamino)heptyl)-5,6,7,8-tetrahydroacridin-9-amine $((R)-3 d)$ and $N$ - $(7-((S)$-3-chloro-5,6,7,8-tetrahydro6-methylacridin-9-ylamino)heptyl)-5,6,7,8-tetrahydroacridin9-amine ((S)-3d)

The heterodimers $(R)$ - and $(S)-\mathbf{3 d}$ were obtained according to general procedure to give a yellow solid 
(46\% yield); m.p. 58-59 ${ }^{\circ} \mathrm{C}$; IR (KBr) $v_{\max } / \mathrm{cm}^{-1} 3412$, 2449, 2854, 1657, 1495, 1419, 1353, 760; ${ }^{1} \mathrm{H}$ NMR $\left(300 \mathrm{MHz}, \mathrm{CDCl}_{3}\right) \delta 1.10(\mathrm{~d}, 3 \mathrm{H}, J 6.6 \mathrm{~Hz}), 1.27-1.47$ (m, 7H), 1.49-1.67 (m, 4H), 1.81-2.04 (m, 6H), 2.49-2.78 (m, 5H), 3.01-3.17 (m, 3H), 3.37-3.57 (m, 4H), 3.81-4.07 (sl, 2H), 7.18-7.38 (m, 2H), 7.43-7.58 (m, 1H), 7.78-8.01 $(\mathrm{m}, 4 \mathrm{H}) ;{ }^{13} \mathrm{C}$ NMR $\left(75 \mathrm{MHz}, \mathrm{CDCl}_{3}\right) \delta 21.6,22.9,23.2$, 24.3, 24.9, 26.9, 28.9, 29.2, 31.0, 34.1, 42.6, 49.5, 49.6, $115.2,116.0,118.5,120.3,122.9,123.7,124.2,124.7$, $127.8,128.4,128.8,134.0,147.5,148.5,150.7,150.8$, 158.5, 159.5; $(R)-3 \mathbf{d}[\alpha]_{\mathrm{D}}{ }^{20}+10^{\circ}(\mathrm{c} 1.12),(S)-3 \mathbf{d}[\alpha]_{\mathrm{D}}{ }^{20}$ $-4^{\circ}$ (c 0.85); HRMS-ESI calcd. for $[\mathrm{M}-\mathrm{H}]^{+}:$541.3093, found: 541.3107 .

\section{Molecular modeling studies of AChE inhibitors}

Currently, there are different three-dimensional structures of the enzyme acetylcholinesterase (AChE) available in the Protein Data Bank complexed to a wide variety of inhibitors. ${ }^{53}$ Due to significant conformational changes observed on the peripheral anionic site (PAS), ${ }^{16}$ we selected five representative conformations of AChE to conduct the ensemble docking experiments. This methodology consists in performing the docking of small ligands in each representative conformation of the receptor aiming to implicitly include the protein flexibility. ${ }^{54}$ Selected structures in this work were $1 \mathrm{ZGC}$ (Torpedo californica), ${ }^{55}$ 2CKM (Torpedo californica), ${ }^{41}$ 1Q83 (Mus musculus), ${ }^{56}$ 1J07 (Mus musculus), ${ }^{57}$ and 4EY7 (Homo sapiens). ${ }^{58}$ The inhibitors from the representative conformations of AChE (i) interact with the CAS, (ii) interact with the PAS, and (iii) are similar to the tacrine inhibitor. The exception is the 1J07, which is complexed with an inhibitor that interacts exclusively with PAS. Five molecules of structural water, preserved in the structures of $\mathrm{AChE}$, were used for the ensemble docking studies.

Isomers, protonation states and tautomers of the ligands were predicted with LigPrep/Epik tool (LigPrep, version 2.9, Schrödinger, LLC, New York, NY, 2014). ${ }^{37}$ Conformations of AChE were prepared with Protein Preparation Wizard tool (Schrödinger Suite 2014-1 Protein Preparation Wizard; Impact version 6.2, Schrödinger, LLC, New York, NY, 2014). The protonation states of the amino acid residues were predicted using PROPKA with $\mathrm{pH}=7$, however, respecting the protonation state of the active site residues already described in the literature: ${ }^{59}$ Glu202 and Glu327 negatively charged and neutral His440:ND1. Tacrine moiety of all inhibitors were predicted to be protonated according to Epik, obtaining a predicted pKa of $9.83 \pm 1.47$ for the tacrine molecule, which corresponds to the experimental value of $9.8 .^{36}$ This protonation state is essential since tacrine moieties donates a hydrogen bond to the carbonyl oxygen of the catalytic His440 main chain. ${ }^{55}$ An optimization of the hydrogen bond network between protein and inhibitor were performed to adjust the orientation of the hydrogen atoms and all hydrogen atoms were submitted to an energy minimization process keeping the heavy atoms fixed.

Ensemble docking experiments were performed with the molecular docking program Glide with SP (standard precision) mode (Glide, version 6.2, Schrödinger, LLC, New York, NY, 2014). ${ }^{60-62}$ Best pose of each ligand was selected according to the Glide Emodel. Comparison between different isomers and inhibitors were carried out according to the score provided by the DockTScore. ${ }^{54,63}$ The ligands co-crystallized were redocked into their respective $\mathrm{AChE}$ conformation to validate the docking protocol.

\section{Molecular modeling of BuChE}

We were not capable to obtain good binding modes of these compounds with $\mathrm{BuChE}$. This fact is probably due to the smaller size of the original inhibitors complexed with the $\mathrm{BuChE}$, when compared with the larger compounds tested in this work, leading to a conformation of the binding site with not enough space for accommodating such large inhibitors (unfortunately there is no experimental structure available of BuChE complexed with bis-tacrine analogues).

\section{Microplate assay for AChE and BuChE activities}

$\mathrm{AChE}$ and BuChE inhibitory activities were measured using a 96-well microplate reader by the colorimetric Ellman's method. ${ }^{64}$ Both enzymes hydrolyze the substrate acetyl and butyrylcholinesterase resulting in the product thiocholine, which reacts with Ellman's reagent (DTNB), producing the yellow anion 2-nitrobenzoate5 -mercaptothiocholine, detected at $405 \mathrm{~nm}$. The enzymes sources used in the present study were rat brain homogenates (AChE) and human plasma (BuChE). All experiments were conducted after approval by the Animal Care and Ethics Committee of the Universidade Federal do Rio Grande do Sul. In order to obtain the AChE source, Wistar male rats (3 months) were decapitated, brains were quickly dissected on ice into cortex and homogenized in cold $10 \mathrm{mM}$ Tris- $\mathrm{HCl}$ buffer, $\mathrm{pH} 7.2$ containing $160 \mathrm{mM}$ sucrose. The homogenates were centrifuged at $10,000 \times \mathrm{g}$ for $10 \mathrm{~min}$ at $4{ }^{\circ} \mathrm{C}$ and the supernatants were used as enzyme sources. For BuChE sources, human plasma was obtained from a female healthy volunteer with written consent and the protocol was approved by the Human Ethic Committee of the Universidade Federal do Rio Grande do Sul. Samples were centrifuged at $1,000 \times \mathrm{g}$ for $15 \mathrm{~min}$ at room temperature. 
The samples of both enzymes were stored at $-20^{\circ} \mathrm{C}$. In the 96-well plates, the test compounds were incubated during $30 \mathrm{~min}$ in various concentrations at $25^{\circ} \mathrm{C}$ in the presence of $10 \mathrm{mM}$ Ellman's reagent (5,5'-dithiobis-(2-nitrobenzoic acid)) and AChE and BuChE samples in $20 \mathrm{mM}$ phosphate buffer $\mathrm{pH}$ 7.4. Then, the substrates acetyltiocholine iodide or $S$-butyrylthiocholine iodide $(0.8 \mathrm{mM})$, respectively, were added, and the absorbance was measured every $30 \mathrm{~s}$ for $180 \mathrm{~s}$ at $405 \mathrm{~nm}$. Protein concentration for both type of enzymes were measured by Peterson' ${ }^{65}$ modification of the procedure of Lowry et al. ${ }^{66}$ using bovine serum albumin as standard. The concentration of each compound to produce $50 \%$ of enzyme activity inhibition $\left(\mathrm{IC}_{50}\right)$ was estimated by nonlinear regression analysis of the response-concentration (log) curve, using the GraFit 7 program package (GraFit 7 Software; Horley, UK). Results are expressed as the mean \pm SEM (standard error of the mean) of at least three different experiments performed in triplicate.

\section{Supplementary Information}

Supplementary data $\left({ }^{1} \mathrm{H}\right.$ and ${ }^{13} \mathrm{C}$ NMR spectra) are available free of charge at http://jbcs.sbq.org.br as PDF file.

\section{Acknowledgments}

We would like to thank the following Brazilian agencies for financial support and fellowships: CNPq, FAPERGS, CAPES, PROPESQ-UFRGS, LNCC.

\section{References}

1. Kumar, A.; Singh, A.; Ekavali; Pharmacol. Rep. 2015, 67, 195.

2. Alzheimer's Association; Alzheimer's Dementia 2014, 10, e47.

3. de Aquino, R. A. N.; Modolo, L. V.; Alves, R. B.; de Fatima, A.; Curr. Drug Targets 2013, 14, 378.

4. Xie, S.-S.; Wang, X.; Jiang, N.; Yu, W.; Wang, K. D. G.; Lan, J.-S.; Li, Z.-R.; Kong, L.-Y.; Eur. J. Med. Chem. 2015, 95, 153.

5. Bartus, R. T.; Dean, R. L.; Beer, B.; Lippa, A. S.; Science 1982, 217, 408.

6. Francis, P. T.; Palmer, A. M.; Snape, M.; Wilcock, G. K.; J. Neurol., Neurosurg. Psychiatry 1999, 66, 137.

7. Fernández-Bachiller, M. I.; Pérez, C.; Monjas, L.; Rademann, J.; Rodríguez-Franco, M. I.; J. Med. Chem. 2012, 55, 1303.

8. Smith, D. A.; Am. J. Health-Syst. Pharm. 2009, 66, 899.

9. Grossberg, G. T.; Pejović, V.; Miller, M. L.; Graham, S. M.; Dementia Geriatr. Cognit. Disord. 2009, 27, 164.

10. Kozurkova, M.; Hamulakova, S.; Gazova, Z.; Paulikova, H.; Kristian, P.; Pharmaceuticals 2011, 4, 382.

11. Terry, A. V.; Callahan, P. M.; Hall, B.; Webster, S. J.; Pharmacol., Biochem. Behav. 2011, 99, 190.
12. Savini, L.; Gaeta, A.; Fattorusso, C.; Catalanotti, B.; Campiani, G.; Chiasserini, L.; Pellerano, C.; Novellino, E.; McKissic, D.; Saxena, A.; J. Med. Chem. 2003, 46, 1.

13. Delfino, R. T.; Ribeiro, T. S.; Figueroa-Villar, J. D.; J. Braz. Chem. Soc. 2009, 20, 407.

14. Li, W.; Mak, M.; Jiang, H.; Wang, Q.; Pang, Y.; Chen, K.; Han, Y.; Neurother. J. Am. Soc. Exp. Neurother. 2009, 6, 187.

15. Bajda, M.; Więckowska, A.; Hebda, M.; Guzior, N.; Sotriffer, C. A.; Malawska, B.; Int. J. Mol. Sci. 2013, 14, 5608.

16. Johnson, G.; Moore, S. W.; Curr. Pharm. Des. 2006, 12, 217.

17. Nawaz, S. A.; Ayaz, M.; Brandt, W.; Wessjohann, L. A.; Westermann, B.; Biochem. Biophys. Res. Commun. 2011, 404, 935.

18. Darvesh, S.; Hopkins, D. A.; Geula, C.; Nat. Rev. Neurosci. 2003, 4, 131.

19. Tasker, A.; Perry, E. K.; Ballard, C. G.; Expert Rev. Neurother. 2005, 5, 101.

20. Hardy, J.; Selkoe, D. J.; Science 2002, 297, 353.

21. Lahiri, D. K.; Farlow, M. R.; Sambamurti, K.; Greig, N. H.; Giacobini, E.; Schneider, L. S.; Curr. Drug Targets 2003, 4, 97.

22. Greig, N. H.; Utsuki, T.; Yu, Q.; Zhu, X.; Holloway, H. W.; Perry, T.; Lee, B.; Ingram, D. K.; Lahiri, D. K.; Curr. Med. Res. Opin. 2001, 17, 159.

23. Rivera-Becerril, E.; Joseph-Nathan, P.; Pérez-Álvarez, V. M.; Morales-Ríos, M. S.; J. Med. Chem. 2008, 51, 5271.

24. Rice-Evans, C. A.; Miller, N. J.; Paganga, G.; Free Radical Biol. Med. 1996, 20, 933.

25. Youdim, M. B. H.; Edmondson, D.; Tipton, K. F.; Nat. Rev. Neurosci. 2006, 7, 295.

26. Castro, A.; Martinez, A.; Mini Rev. Med. Chem. 2001, 1, 267.

27. Davis, K. L.; Powchik, P.; Lancet 1995, 345, 625.

28. Recanatini, M.; Cavalli, A.; Belluti, F.; Piazzi, L.; Rampa, A.; Bisi, A.; Gobbi, S.; Valenti, P.; Andrisano, V.; Bartolini, M.; Cavrini, V.; J. Med. Chem. 2000, 43, 2007.

29. McKenna, M. T.; Proctor, G. R.; Young, L. C.; Harvey, A. L.; J. Med. Chem. 1997, 40, 3516.

30. Pisoni, D. S.; da Costa, J. S.; Gamba, D.; Petzhold, C. L.; Borges, A. C. A.; Ceschi, M. A.; Lunardi, P.; Gonçalves, C. A. S.; Eur. J. Med. Chem. 2010, 45, 526.

31. Drukarch, B.; Leysen, J. E.; Stoof, J. C.; Life Sci. 1988, 42, 1011.

32. Chuh, A. A. T.; JHKC Psych. 1993, 3, 51.

33. Proctor, G. R.; Harvey, A. L.; Curr. Med. Chem. 2000, 7, 295.

34. Frideling, A.; Faure, R.; Galy, J.-P.; Kenz, A.; Alkorta, I.; Elguero, J.; Eur. J. Med. Chem. 2004, 39, 37.

35. Bañón-Caballero, A.; Guillena, G.; Nájera, C.; J. Org. Chem. 2013, 78, 5349.

36. Desai, M. C.; Thadeio, P. F.; Lipinski, C. A.; Liston, D. R.; Spencer, R. W.; Williams, I. H.; Bioorg. Med. Chem. Lett. 1991, $1,411$. 
37. Shelley, J. C.; Cholleti, A.; Frye, L. L.; Greenwood, J. R.; Timlin, M. R.; Uchimaya, M.; J. Comput.-Aided Mol. Des. 2007, 21, 681.

38. Soukup, O.; Jun, D.; Zdarova-Karasova, J.; Patocka, J.; Musilek, K.; Korabecny, J.; Krusek, J.; Kaniakova, M.; Sepsova, V.; Mandikova, J.; Trejtnar, F.; Pohanka, M.; Drtinova, L.; Pavlik, M.; Tobin, G.; Kuca, K.; Curr. Alzheimer Res. 2013, 10, 893.

39. Korabecny, J.; Musilek, K.; Holas, O.; Binder, J.; Zemek, F.; Marek, J.; Pohanka, M.; Opletalova, V.; Dohnal, V.; Kuca, K.; Bioorg. Med. Chem. Lett. 2010, 20, 6093.

40. Pang, Y. P.; Quiram, P.; Jelacic, T.; Hong, F.; Brimijoin, S.; J. Biol. Chem. 1996, 271, 23646.

41. Rydberg, E. H.; Brumshtein, B.; Greenblatt, H. M.; Wong, D. M.; Shaya, D.; Williams, L. D.; Carlier, P. R.; Pang, Y.-P.; Silman, I.; Sussman, J. L.; J. Med. Chem. 2006, 49, 5491.

42. de Aquino, R. A. N.; Modolo, L. V.; Alves, R. B.; de Fátima, Â.; Org. Biomol. Chem. 2013, 11, 8395.

43. Bolognesi, M. L.; Minarini, A.; Rosini, M.; Tumiatti, V.; Melchiorre, C.; Mini Rev. Med. Chem. 2008, 8, 960.

44. Schmidt, I.; Pradel, G.; Sologub, L.; Golzmann, A.; Ngwa, C. J.; Kucharski, A.; Schirmeister, T.; Holzgrabe, U.; Bioorg. Med. Chem. 2016, 24, 3636.

45. Djerassi, C.; Krakower, G. W.; J. Am. Chem. Soc. 1959, 81, 237.

46. Ordentlich, A.; Barak, D.; Sod-Moriah, G.; Kaplan, D.; Mizrahi, D.; Segall, Y.; Kronman, C.; Karton, Y.; Lazar, A.; Marcus, D.; Velan, B.; Shafferman, A.; Chem. Biol. Interact. 2005, 157-158, 191.

47. Bacalhau, P.; San Juan, A. A.; Goth, A.; Caldeira, A. T.; Martins, R.; Burke, A. J.; Bioorg. Chem. 2016, 67, 105.

48. Dvir, H.; Jiang, H. L.; Wong, D. M.; Harel, M.; Chetrit, M.; He, X. C.; Jin, G. Y.; Yu, G. L.; Tang, X. C.; Silman, I.; Bai, D. L.; Sussman, J. L.; Biochemistry (Mosc.) 2002, 41, 10810.

49. da Costa, J. S.; Pisoni, D. S.; da Silva, C. B.; Petzhold, C. L.; Russowsky, D.; Ceschi, M. A.; J. Braz. Chem. Soc. 2009, 20, 1448 .

50. da Costa, J. S.; Lopes, J. P. B.; Russowsky, D.; Petzhold, C. L.; Borges, A. C. A.; Ceschi, M. A.; Konrath, E.; Batassini, C.; Lunardi, P. S.; Gonçalves, C. A. S.; Eur. J. Med. Chem. 2013, $62,556$.

51. Ceschi, M. A.; da Costa, J. S.; Lopes, J. P. B.; Câmara, V. S.; Campo, L. F.; Borges, A. C. A.; Gonçalves, C. A. S.; de Souza, D. F.; Konrath, E. L.; Karl, A. L. M.; Guedes, I. A.; Dardenne, L. E.; Eur. J. Med. Chem. 2016, 121, 758.
52. Luo, W.; Li, Y.-P.; He, Y.; Huang, S.-L.; Tan, J.-H.; Ou, T.-M.; Li, D.; Gu, L.-Q.; Huang, Z.-S.; Bioorg. Med. Chem. 2011, 19, 763.

53. Bernstein, F. C.; Koetzle, T. F.; Williams, G. J.; Meyer Jr., E. F.; Brice, M. D.; Rodgers, J. R.; Kennard, O.; Shimanouchi, T.; Tasumi, M.; J. Mol. Biol. 1977, 112, 535.

54. Guedes, I. A.; de Magalhães, C. S.; Dardenne, L. E.; Biophys. Rev. 2014, 6, 75.

55. Haviv, H.; Wong, D. M.; Greenblatt, H. M.; Carlier, P. R.; Pang, Y.-P.; Silman, I.; Sussman, J. L.; J. Am. Chem. Soc. 2005, 127, 11029.

56. Bourne, Y.; Kolb, H. C.; Radic, Z.; Sharpless, K. B.; Taylor, P.; Marchot, P.; Proc. Natl. Acad. Sci. U. S. A. 2004, 101, 1449.

57. Bourne, Y.; Taylor, P.; Radić, Z.; Marchot, P.; EMBO J. 2003, $22,1$.

58. Cheung, J.; Rudolph, M. J.; Burshteyn, F.; Cassidy, M. S.; Gary, E. N.; Love, J.; Franklin, M. C.; Height, J. J.; J. Med. Chem. 2012, 55, 10282.

59. Hedstrom, L.; Chem. Rev. 2002, 102, 4501.

60. Friesner, R. A.; Murphy, R. B.; Repasky, M. P.; Frye, L. L.; Greenwood, J. R.; Halgren, T. A.; Sanschagrin, P. C.; Mainz, D. T.; J. Med. Chem. 2006, 49, 6177.

61. Friesner, R. A.; Banks, J. L.; Murphy, R. B.; Halgren, T. A.; Klicic, J. J.; Mainz, D. T.; Repasky, M. P.; Knoll, E. H.; Shelley, M.; Perry, J. K.; Shaw, D. E.; Francis, P.; Shenkin, P. S.; J. Med. Chem. 2004, 47, 1739.

62. Halgren, T. A.; Murphy, R. B.; Friesner, R. A.; Beard, H. S.; Frye, L. L.; Pollard, W. T.; Banks, J. L.; J. Med. Chem. 2004, 47, 1750.

63. de Magalhães, C. S.; Almeida, D. M.; Barbosa, H. J. C.; Dardenne, L. E.; Inf. Sci. 2014, 289, 206.

64. Ellman, G. L.; Courtney, K. D.; Andres, V.; Featherstone, R. M.; Biochem. Pharmacol. 1961, 7, 88.

65. Peterson, G. L.; Anal. Biochem. 1977, 83, 346.

66. Lowry, O. H.; Rosebrough, N. J.; Farr, A. L.; Randall, R. J.; J. Biol. Chem. 1951, 193, 265.

Submitted: February 8, 2017

Published online: April 25, 2017

FAPERGS/CAPES has sponsored the publication of this article. 